\title{
Stubby-Root Nematode, Trichodorus obtusus Cobb (Nematoda: Adenophorea: Triplonchida: Diphtherophorina: Trichodoridea: Trichodoridae) ${ }^{1}$
}

W. T. Crow $^{2}$

\section{Introduction}

Nematodes in the family Trichodoridae (Thorne, 1935) Siddiqi, 1961, are commonly called "stubby-root" nematodes, because feeding by these nematodes can cause a stunted or "stubby" appearing root system. Trichodorus obtusus is one of the most damaging nematodes on turfgrasses, but also may cause damage to other crops.

\section{Synonymy}

\section{Trichodorus proximus}

\section{Distribution}

Trichodorus obtusus is only known to occur in the United States. A report of $T$. proximus (a synonym of $T$. obtusus) from Ivory Coast was later determined to be a different species. Trichodorus obtusus is reported in the states of Virginia, Florida, Iowa, Kansas, Michigan, New York and South Dakota. The author found T. obtusus infesting St. Augustinegrass lawns near Dallas, Texas.

\section{Life Cycle and Biology}

While large for a plant-parasitic nematode (about $1 / 16$ inch long), $T$. obtusus is still small enough that it can be seen only with the aid of a microscope. Stubby-root nematodes are ectoparasitic nematodes, meaning that they feed on plants while their bodies remain in the soil. They feed primarily on meristem cells of root tips. Stubby-root nematodes are plant-parasitic nematodes in the Triplonchida, an order characterized by having a six-layer cuticle (body covering). Stubby- root nematodes are unique among plant-parasitic nematodes because they have an onchiostyle, a curved, solid stylet or spear they use in feeding. All other plant-parasitic nematodes have straight, hollow stylets. Stubby-root nematodes use their onchiostyle like a dagger to puncture holes in plant cells. The stubby root nematode then secretes from its mouth (stoma) salivary material into the punctured cell. The salivary material hardens into a feeding tube which functions as a "straw" enabling the nematode to withdraw and ingest the cell contents through the tube. After feeding on an individual cell, the stubby-root nematode will move on to feed on

1. This document is EENY-340, one of a series of Featured Creatures from the Entomology and Nematology Department, Florida Cooperative Extension Service, Institute of Food and Agricultural Sciences, University of Florida. Published: November 2004. This document is also available on Featured Creatures Website at http://creatures.ifas.ufl.edu. Please visit the EDIS Website at http://edis.ifas.ufl.edu.

2. W. T. Crow, Department of Entomology and Nematology, Insitute of Food and Agricultural Sciences, University of Florida, Gainesville, FL.

The Institute of Food and Agricultural Sciences (IFAS) is an Equal Opportunity Institution authorized to provide research, educational information and other services only to individuals and institutions that function with non-discrimination with respect to race, creed, color, religion, age, disability, sex, sexual orientation, marital status, national origin, political opinions or affiliations. U.S. Department of Agriculture, Cooperative Extension Service, University of Florida, IFAS, Florida A. \& M. University Cooperative Extension Program, and Boards of County Commissioners Cooperating. Larry Arrington, Dean 


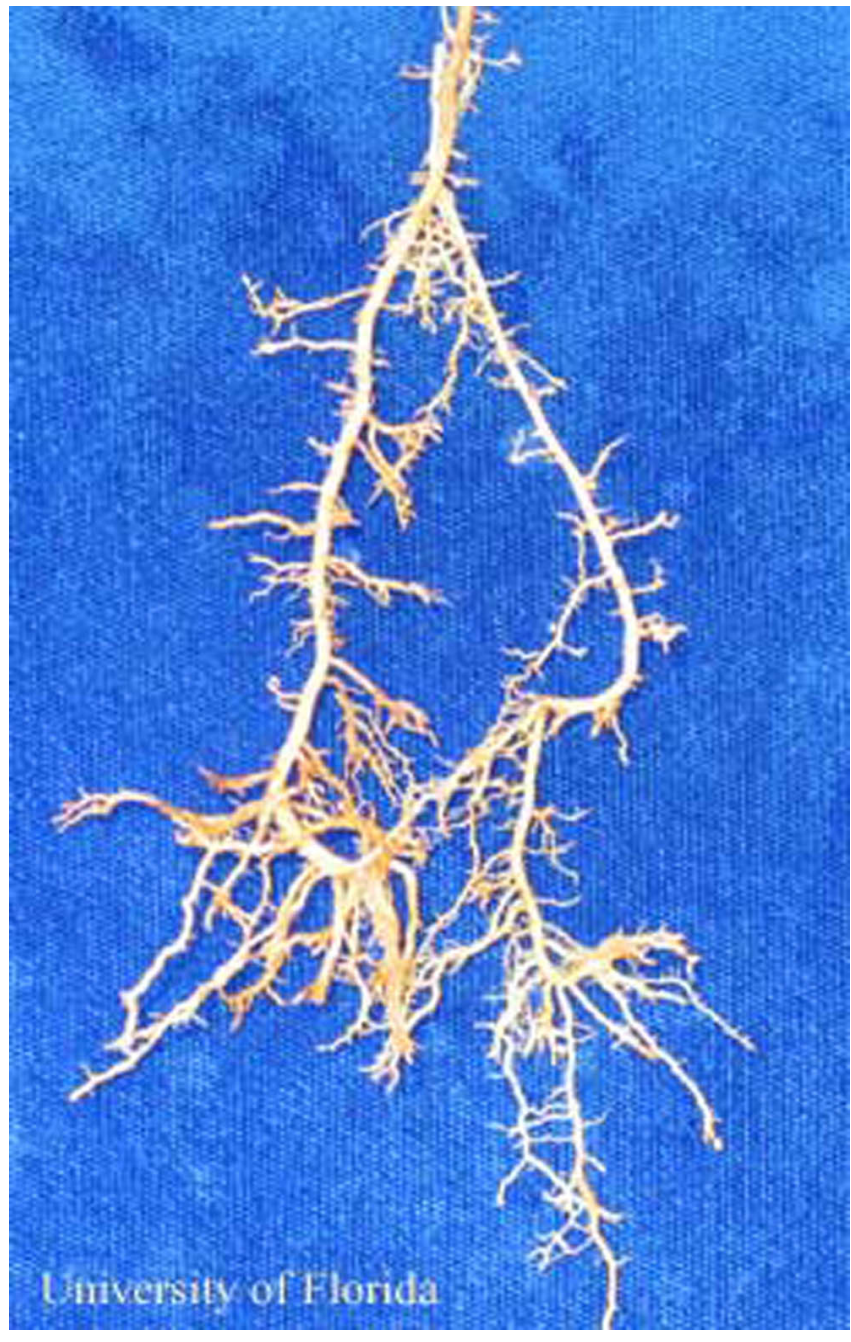

Figure 1. St. Augustinegrass roots with "stubby-root" symptoms caused by Trichodorus obtusus Cobb, a stubby-root nematode. Credits: W. T. Crow, University of Florida

other cells, leaving old feeding tubes behind and forming new ones in each cell that it feeds from.

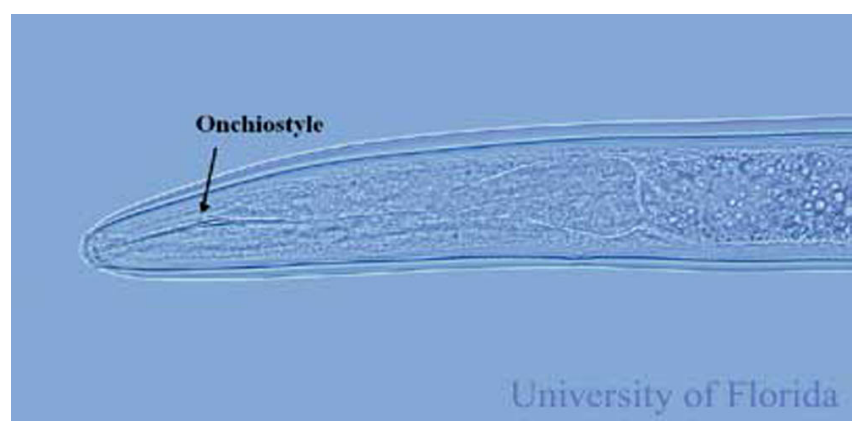

Figure 2. Curved onchiostyle of Trichodorus obtusus Cobb, a stubby-root nematode. Credits: W. T. Crow, University of Florida

Trichodorus obtusus is an amphimictic species, meaning that males and females must mate to

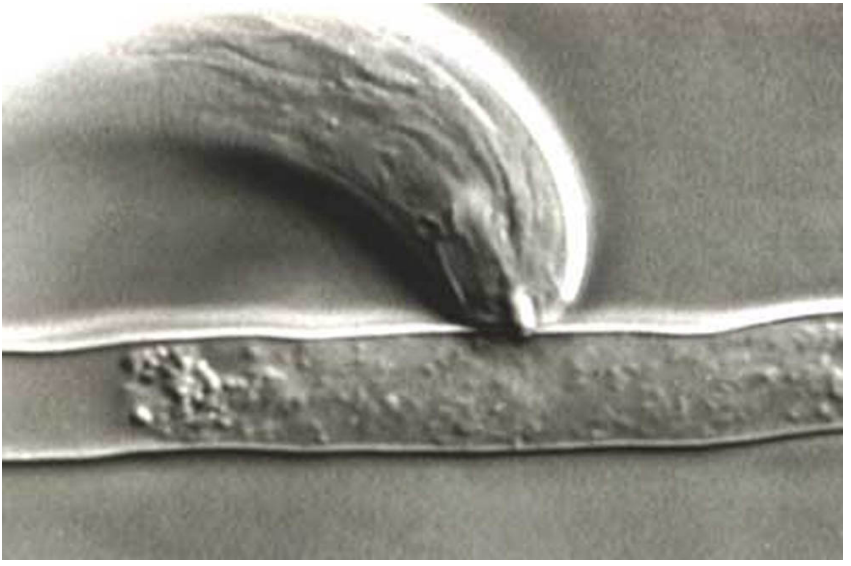

Figure 3. Stubby-root nematode feeding on a root hair through a feeding tube. Credits: Urs Wyss, Institute of Phytopathology, Germany

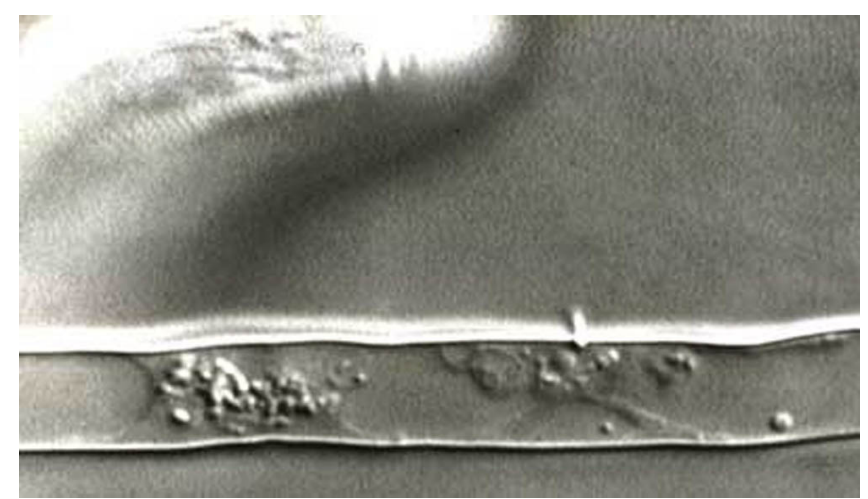

Figure 4. Feeding tube left in a root hair after feeding by a stubby-root nematode. Credits: W. T. Crow, University of Florida

produce offspring. Therefore, in most populations there are almost as many males as females. After mating, female $T$. obtusus lay eggs that remain in soil until they hatch as second-stage juveniles.

Stubby-root nematodes are obligate plant-parasites, meaning they must feed on plants in order to survive and reproduce. Once it locates a root and starts feeding, the juvenile nematode will molt three times before it becomes an egg-laying adult.

\section{Importance}

Trichodorus obtusus is very damaging on turfgrasses. In Florida it is one of the most common nematode problems diagnosed on St. Augustinegrass lawns. By damaging the turf root system it makes the turf more prone to environmental stresses and may lead to increased use of water and fertilizer inputs. It also makes turf less competitive with weeds and may lead to increased herbicide usage. 


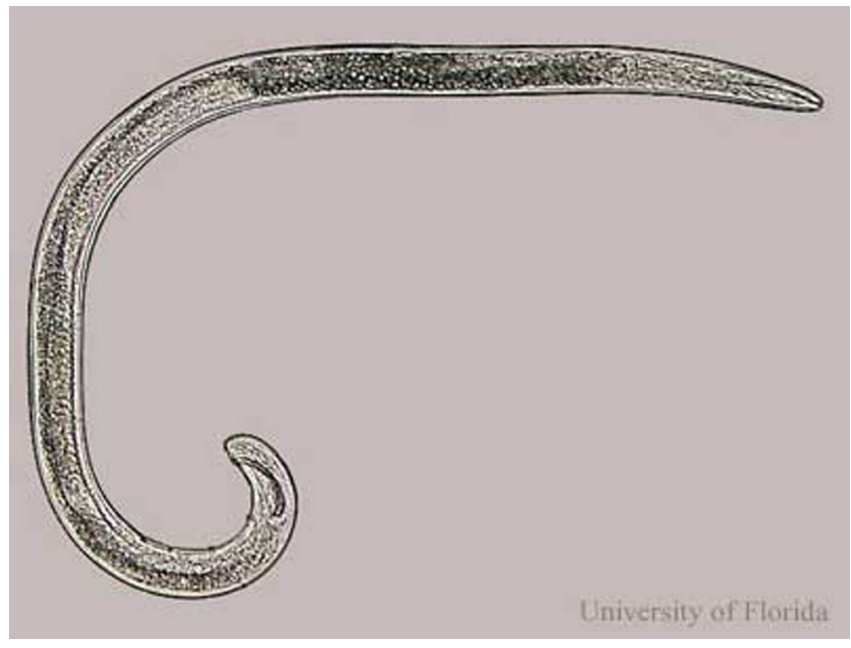

Figure 5. Male Trichodorus obtusus Cobb, a stubby-root nematode. Credits: W. T. Crow, University of Florida

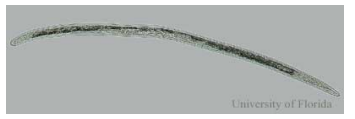

Figure 6. Female Trichodorus obtusus Cobb, a stubby-root nematode. Credits: W. T. Crow, University of Florida

\section{Symptoms}

On turfgrasses, damage caused by T. obtusus usually occurs in irregularly shaped patches within a given area. Symptoms are usually worse in sandy than in heavier soils. The turf may wilt in these areas, thin out, and die if stresses such as drought occur. Roots may appear abbreviated or "stubby" looking. However, these symptoms can be caused by other factors, so the only way to verify if $T$. obtusus is a problem is to have a nematode assay conducted by a credible nematode diagnostic lab. The University of Florida Nematode Assay Laboratory provides routine diagnosis of T. obtusus, and other plant-parasitic nematodes for the public at a nominal fee.

\section{Hosts}

Known hosts of T. obtusus are: bermudagrass, St. Augustinegrass, and tomato (Lycopersicon esculetum). It has been associated with; big bluestem (Andropogon gerardii), sideoats grama (Bouteloua curtipendula), eucalyptus (Eucalyptus sp.), Kentucky bluegrass (Poa pretensis), rhododendron (Rhododendron sp.), Sabal palm (Sabal palmetto), potato (Solanum tuberosum), littleleaf linden (Tilia cordata), sweetbay magnolia (Magnolia virginiana), sorghum-sudangrss (Sorghum bicolor x $S$.

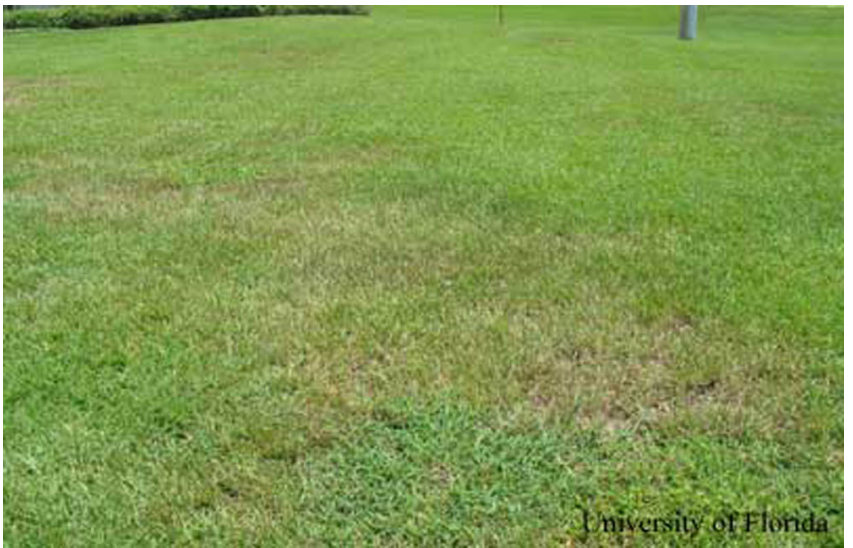

Figure 7. Wilting patches of St. Augustinegrass resulting from a high infestation of Trichodorus obtusus Cobb, a stubby-root nematode. Credits: W. T. Crow, University of Florida

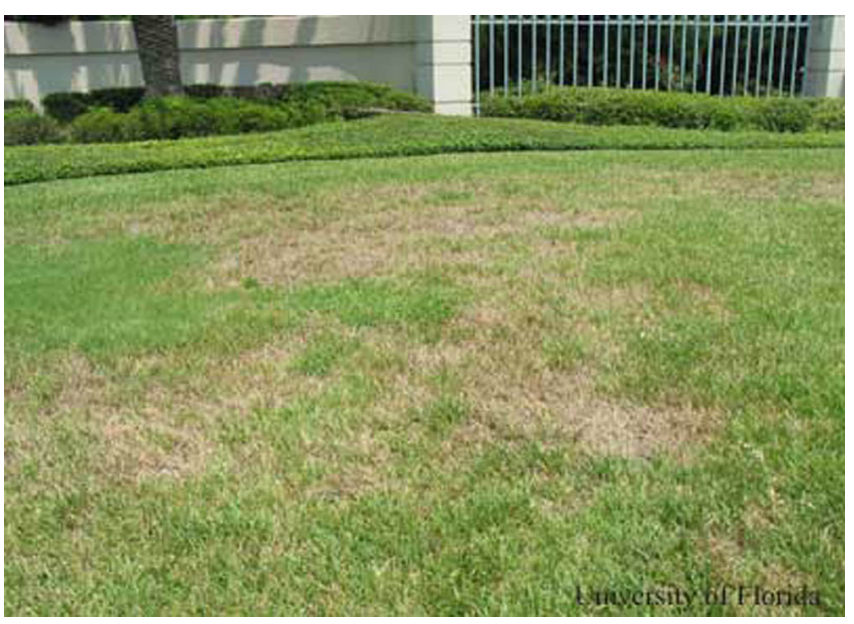

Figure 8. Dying patches of St. Augustinegrass resulting from a high infestation of Trichodorus obtusus Cobb, a stubby-root nematode, combined with drought stress. Credits: W. T. Crow, University of Florida

arundinaceum) and seashore paspalum (Paspalum vaginatum).

\section{Management}

Nematicides are available for use on golf courses, sod farms, cemeteries, athletic fields, and industrial grounds. However, no effective nematicides are currently available for use on residential lawns.

See the University of Florida Nematode Management Guide for current nematicide recommendations.

Often, if other turf stress factors such as improper mowing, insufficient light, poor irrigation 


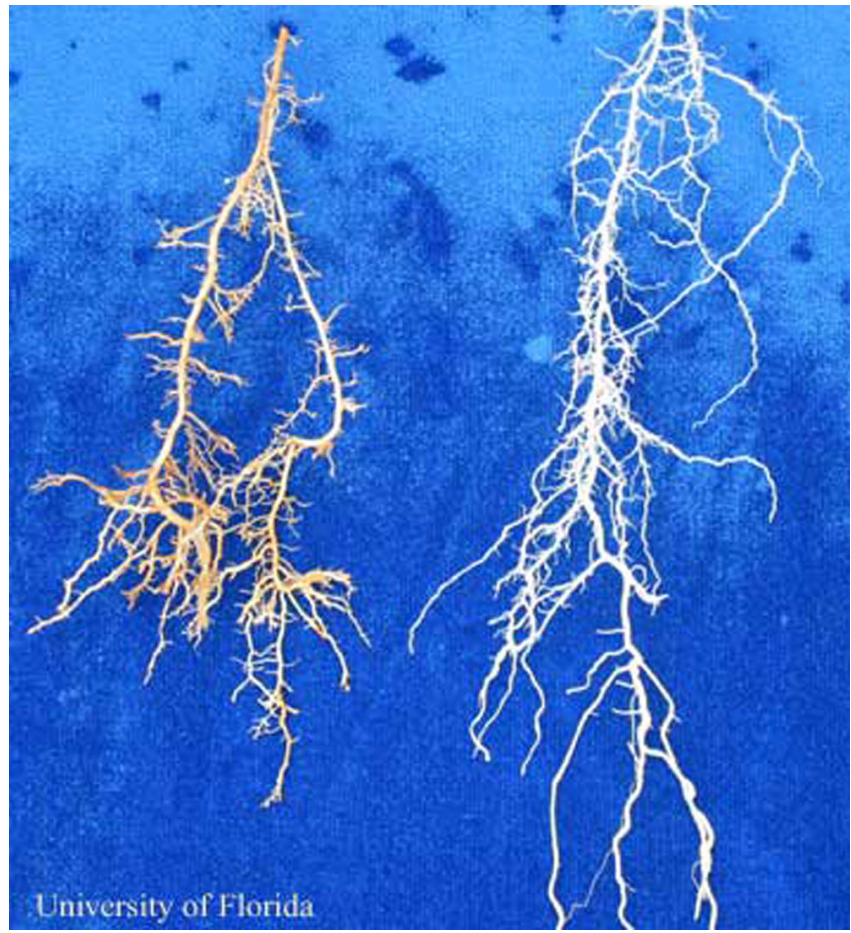

Figure 9. St. Augustinegrass roots grown in soil inoculated with Trichodorus obtusus (left), a stubby-root nematode, and in non-inoculated soil (right). Credits: W. T. Crow, University of Florida

coverage, etc. can be identified, damage caused by $T$. obtusus can be lessened by improving these conditions. Increasing irrigation frequency also can help, but may not be practical during times of water restriction.

In extreme cases it may become practical to replace infested grass with an alternative planting. In these cases rhizomal or perinneal peanut may make an acceptable turf substitute that is immune to $T$. obtusus.

\section{Selected References}

Crow WT. 2004. Diagnosis of Trichodorus obtusus and Paratrichodorus minor on turfgrasses in the Southeastern United States. Plant Health Progress: in press.

Crow WT, Welch JK. 2004. Root reductions of St. Augustinegrass (Stenotaphrum secundatum) and hybrid bermudagrass (Cynodon dactylon x $C$. transvaalensis) induced by Trichodorus obtusus and Paratrichodorus minor. Nematropica: in press.
Decreamer W. 1991. Stubby root and virus vector nematodes. p.587-625 In Nickle WR (ed.) Manual of Agricultural Nematology. Macel Dekker, Inc. New York.

Hunt DJ. 1993. Aphelenchida, Longidoridae and Trichodoridae: Their systematics and bionomics.

CAB International, Wallingford, UK.

Rhoades HL. 1965. Parasitism and pathogenicity of Trichodorus proximus to St. Augustine grass. Plant Disease Reporter 49:259-262. 